\section{Serological evidence of exposure to some zoonotic microorganisms in cattle and humans with occupational exposure to livestock in Antioquia, Colombia}

\section{Evidencia serológica de exposición a algunos microorganismos zoonóticos en bovinos y humanos con exposición ocupacional a ganadería en Antioquia, Colombia}

\section{Evidências sorológicas de exposição a alguns microrganismos zoonóticos em bovinos e em humanos com exposição ocupacional ao gado na Antióquia, Colômbia}

\begin{abstract}
Bacteria belonging to Anaplasma, Ehrlichia, Rickettsia and Coxiella genera are considered emerging pathogens and livestock is one of the contexts where the transmission of these microorganisms can occur. The goal of this study was to determine serological evidence for the exposure to these bacteria in cattle and humans with occupational exposure to livestock in the subregions North and Magdalena Medio, Antioquia, Colombia, and to explore related factors. A cross-sectional study was conducted in 48 livestock farms distributed in six municipalities from both subregions: Belmira, Entrerrios and San Pedro de los Milagros (North), and Puerto Berrío, Puerto Nare and Puerto Triunfo (Magdalena Medio). Blood samples from 332 people and 384 bovines were evaluated by serology (IgM and $\operatorname{Ig} G$ ) screening for bacteria from the Anaplasma, Ehrlichia, Rickettsia, and Coxiella genera. Seropositivity in humans from both regions was 42.4\% (95\% CI: 31.2-55.1) for Anaplasma, 74.2\% (95\%CI: 66.0-84.4) for Ehrlichia, 72.5\% (95\%CI: 62.1-82.0) for Rickettsia, and 60.7\% (95\%CI: 59.7-69.1) for Coxiella burnetii. In cattle, seropositivity was 31.6\% (95\% CI: 19.9-44.2), 66.8\% (95\%CI: 55.2-78.1), 64.6\% (95\%CI: 53.8-74.5), and 61.6\% (95\%CI: 51.9-69.2), respectively. History of biting by ticks, milking, vaccination, having dogs and hens in the residence, as well as the consumption of raw milk derivatives were some factors associated with the infection by the bacteria studied. The results suggest a previous and recent exposure to these zoonotic bacteria genera in people with occupational exposure to livestock, as well as in cattle in the two studied subregions.
\end{abstract}

Marcela Patricia Eraso-Cadena 1 Licet Paola Molina-Guzmán 1,2 Ximena Cardona 3 Jaiberth Antonio Cardona-Arias 2 Leonardo Alberto Ríos-Osorio 2 Lina Andrea Gutierrez-Builes 1

doi: 10.1590/0102-311X00193617

\author{
Correspondence \\ L. A. Gutierrez-Builes \\ Grupo Biología de Sistemas, Escuela de Ciencias de la Salud, \\ Facultad de Medicina, Universidad Pontificia Bolivariana. \\ Calle 78 B \# 72 A 109, Bloque B (Lab de investigaciones), \\ Medellin / Antioquia - 050034, Colombia. \\ lina.gutierrezb@upb.edu.co \\ 1 Facultad de Medicina, Universidad Pontificia Bolivariana, \\ Medellin, Colombia. \\ 2 Escuela de Microbiología, Universidad de Antioquia, Medellín, \\ Colombia. \\ 3 Departamento de Asistencia Técnica, COLANTA, Medellín, \\ Colombia.
}




\section{Introduction}

Tick-transmitted infectious diseases in humans are considered zoonotic diseases 1. The livestock industry is one of the settings where such microorganisms are often detected, and the World Health Organization (WHO) considers this agricultural activity as one of the seven professional groups that is especially exposed to various zoonotic agents, given their close relationship with animals or their by-products, and the ongoing bidirectional transmission of diverse microorganisms 2 .

In Colombia, livestock farming occurs over the national territory as a major economic activity. The department of Antioquia hosts the largest bovine population of the country, where the Urabá, North, and Magdalena Medio subregions stand out as the largest producers at department level 3. Tick-borne diseases cause large economic losses, affecting cattle health and reducing the quality of by-products from the production system, such as meat, milk, and skins ${ }^{4}$. The World Organization for Animal Health (OIE) suggests that some of these infectious diseases should be compulsorily reported for timely diagnosis and control due to their impact on animal welfare 5 . However, Colombian surveillance programs often present underreporting regarding the etiological and clinical suspicion of tickborne diseases, further, adequate diagnostic and therapeutic alternatives are currently unavailable.

Tick-borne diseases in humans, such as anaplasmosis, ehrlichiosis, rickettsiosis, and coxiellosis, develop with nonspecific symptoms like fever, headache, myalgia, and arthralgia 6 . This clinical picture overlaps with other epidemiologically relevant pathologies recognized in the Colombian environment, such as malaria and dengue 7 . Consequently, this similarity in symptoms may lead to an underestimation of the diagnosis and inadequate treatment of cases, which are usually recorded as unspecified fevers.

Ticks are obligate hematophagous ectoparasites associated with the transmission of viruses, bacteria, and protozoa that affect both human and animal health 8 . Wild and domestic animals are part of their life cycle. The distribution of ticks at heights over 2,600 meters above the sea level (m.a.s.l.) ${ }^{9}$ and the microorganism-transmission capacity at the transovarial and transstadial stages inherent to its life cycle, created the conditions for the maintenance of a steady population size over time, therefore increasing the risk of pathogenic microorganism transmission to diverse hosts 10. In the Colombian livestock context, different tick species have been found to be naturally infected by Babesia 11, Rickettsia 12, Anaplasma and Ehrlichia ${ }^{13}$ genera, making them potential biological vectors. In addition, there are reports of human clinical cases of babesiosis 14 , anaplasmosis 15 , ehrlichiosis 14 and coxiellosis 16 associated with livestock activities.

Considering the representativeness of the North and Magdalena Medio subregions in livestock production in the department of Antioquia, Colombia, this study sought to determine, through serology screening, the level of exposure of cattle and people occupationally engaged in livestock activities to some tick-transmitted zoonotic agents, and to explore the associated factors with their detection in the studied subregions.

\section{Methods}

\section{Design and place of study}

A cross-sectional study was performed in 48 farms in the North and Magdalena Medio subregions of Antioquia. For the North subregion, the study was conducted from September to October 2014, in the municipalities of Belmira, Entrerríos and San Pedro de los Milagros, where the temperature range from 13 to $19^{\circ} \mathrm{C}, 79 \%$ relative humidity, and the altitude range is 1,850 to 2,540 m.a.s.l. For the Magdalena Medio subregion, from October to November 2015, in the municipalities of Puerto Berrío, Puerto Nare and Puerto Triunfo, where the temperature ranges from 32 to $43^{\circ} \mathrm{C}, 53 \%$ relative humidity, and the altitude ranges from 125 to 150 m.a.s.l. These environmental conditions were verified during field sampling using a portable meteorological station (Ambient WS-2080; Ambient Weather, Chandler, U.S.A.). The estimated sample size for cattle and humans was proportionally distributed among eight cattle herds from the six municipalities included in this study (48 total herds). Livestock herds were selected in each municipality using simple random sampling on databases provided by the 
main livestock associations in each area. Figure 1 illustrates the geographical distribution of the studied areas. Information on geographical coordinates was collected on the field using the Trimble Juno 3B GPS equipment (Westminster, U.S.A.), and represented using the ArcGIS 10.1 software (http:// www.esri.com/software/arcgis/index.html).

\section{Information collection and processing of blood samples}

This study included males and females over 18 years of age, who had contact with the bovine reference population, and who voluntarily agreed to participate in this research. All participants signed an informed consent form. A structured survey was conducted to collect and describe some sociodemographic, hygiene-sanitary and clinical aspects about each participant. The information about cattle included age, sex, breed and medical and veterinary management history. The blood samples from people and cattle were collected without any preservatives. A multiple test was conducted for the serological screening of cattle and humans, using a single cut-off point (dilution $\geq 1: 16$ ) and a custom-made commercial kit prepared by Fuller Laboratories (Fullerton, U.S.A.). To detect IgM and IgG antibodies an indirect immunofluorescence assay (IFA - the analytical sensitivity and specificity were estimated by the manufacturer in 98-100\%) was used. The plates contained fixed antigens of Anaplasma phagocytophilum, Ehrlichia chaffeensis, Rickettsia rickettsii, and phase I and phase II Coxiella burnetii, obtained from axenic cultures of these microorganisms. Samples were processed, and results were analyzed according to the manufacturer's instructions. Results were read using an Eclipse 55i microscope (Nikon, Tokyo, Japan) with an Intensilight epifluorescence system (Nikon, Tokyo, Japan) using $40 X$ objective lens. Each IFA was read by two independent observers, blind to the sample. In the case of ambiguous readings, a third reading was performed to reach a final consensus. When necessary, the sample was re-processed and read again by both analysts.

The socio-demographic, hygiene-sanitary and clinical characteristics reported by the participants and the registered characteristics of the studied bovine population, were described as means of absolute (n) and relative frequencies (\%) for the qualitative variables, and summary measures for the quantitative variables. Associated factors with seropositivity were explored; crude odds ratio and adjusted odds ratio were estimated using binary logistic regression to control confounding factors. The bivariate (crude association measures) and multivariate analyses (regression-adjusted measures) considered a 0.05 statistical significance level and 95\% confidence level. The standard entry method of simultaneous variables (the enter method) was used for the regression model; all independent variables were entered in the equation at the same time to determine confounding and highly correlated ones. Statistical analysis was performed using the software SPSS for Windows, version 22.0 (IBM SPSS, Armonk, U.S.A.). This study was endorsed by the Ethics Committee on Health Research of the Universidad Pontificia Bolivariana (Record n. 7, May 23, 2012).

\section{Results}

\section{Socio-demographic, clinical, and health description of humans included in the study}

Three hundred and thirty-two people were analyzed in total; 189 subjects from the North subregion and 143 from the Magdalena Medio subregion. In the Northern area, the study group consisted of 166 (87.8\%) men and $23(12.2 \%)$ women with a median age of 40 years. Most of the analyzed population resided in rural areas $(82.5 \%)$ and milking was the most frequent activity on the farm $(74.1 \%)$. The presence of ticks at the farm was reported by $18 \%$ of the population and $5.8 \%$ reported a history of tick bites. Preparation of foods derived from raw milk was reported by $51.3 \%$ of the individuals and usual consumption of foods derived from raw milk by $83.1 \%$. Regarding the presence of domestic animals in the household, dogs were the most reported (71.4\%), followed by cattle (66.7\%) and horses (41.8\%).

Most individuals from the Magdalena Medio subregion were men (82.5\%) with a median age of 42 years. Regarding the place of residence, $83.2 \%$ of the participants lived in rural areas. The main work activities performed at the farm included cattle corralling (44.8\%), milking (44.1\%), and direct routine contact with bovine biological fluids while performing farm-related tasks (66.2\%). The participants 


\section{Figure 1}

Geographic location of the municipalities included in this study.
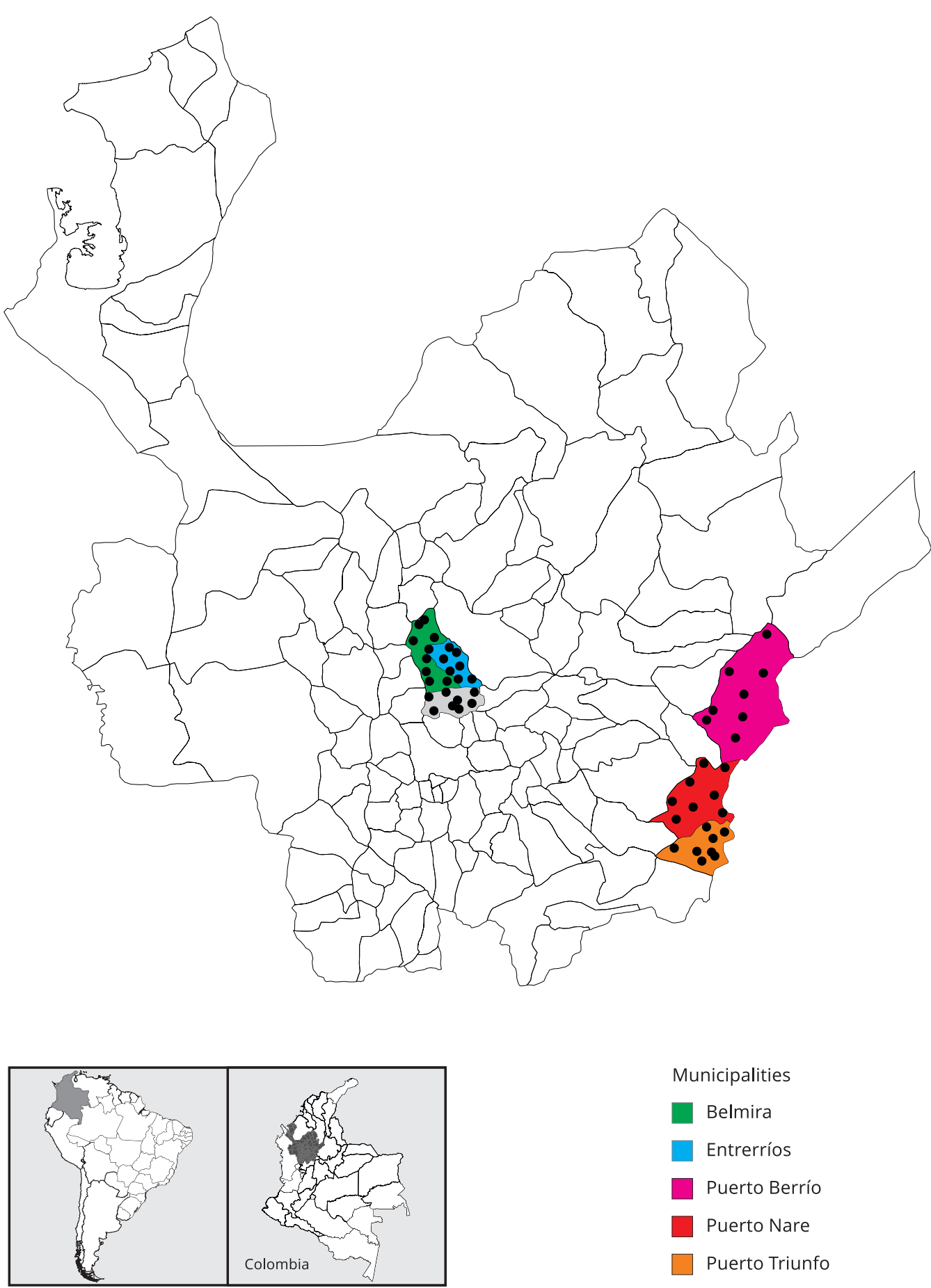

Municipalities

Belmira

Entrerríos

Puerto Berrío

Puerto Nare

$\square$ Puerto Triunfo

San Pedro de los Milagros

Note: geographical localization of the cattle farms included in this study is represented by dots within each of the six municipalities in the Department of Antioquia, Colombia. Overall, 48 farms ( 8 farms per municipality), 332 individuals (189 in the North subregion and 143 in the Magdalena Medio subregion) and 384 cattle (192 in the North subregion and 192 in the Magdalena Medio subregion) were sampled. 
reported high values for the presence of ticks in the farms (85.3\%), as well as a history of tick biting (62.9\%) and involvement of immature ticks in biting (53.1\%). Regarding the possession of domestic animals in the household, dogs (70.6\%) and cattle (70.6\%) were the most frequent. Preparation of foods derived from raw milk was reported by $50.3 \%$ of the individuals, and $59.4 \%$ reported their consumption on a regular basis (Table 1).

Table 1

Socio-demographic, clinical and sanitary characteristics of the participants.

\begin{tabular}{|c|c|c|c|c|}
\hline \multirow[t]{2}{*}{ Variables } & \multicolumn{2}{|c|}{ North } & \multicolumn{2}{|c|}{ Magdalena Medio } \\
\hline & Median & IR & Median & IR \\
\hline Age (years) & 40 & $31-48$ & 42 & $32-50$ \\
\hline Time working with cattle (years) & 19 & $10-30$ & 20 & $10-28$ \\
\hline \multirow[t]{2}{*}{ Time working with cattle (hours/day) } & 8 & $4-9$ & 8 & $1-8$ \\
\hline & $\mathbf{n}$ & $\%$ & $\mathbf{n}$ & $\%$ \\
\hline \multicolumn{5}{|l|}{ Sex } \\
\hline Male & 166 & 87.8 & 118 & 82.5 \\
\hline Female & 23 & 12.2 & 25 & 17.5 \\
\hline \multicolumn{5}{|l|}{ Site of residence } \\
\hline Urban & 33 & 17.5 & 24 & 16.8 \\
\hline Rural & 156 & 82.5 & 119 & 83.2 \\
\hline \multicolumn{5}{|l|}{ Education level (years) } \\
\hline$\leq 5$ & 117 & 61.9 & 95 & 66.4 \\
\hline $6-11$ & 59 & 31.2 & 40 & 28.0 \\
\hline$\geq 12$ & 13 & 6.9 & 8 & 5.6 \\
\hline \multicolumn{5}{|l|}{ Occupational history * } \\
\hline Contact with cattle & 175 & 92.6 & 112 & 78.3 \\
\hline Contact with bovine biological fluids & 156 & 82.5 & 94 & 66.2 \\
\hline Presence of ticks in the farm & 34 & 18.0 & 122 & 85.3 \\
\hline History of tick bites & 11 & 5.8 & 90 & 62.9 \\
\hline History of immature ticks found in their bodies & 9 & 4.8 & 76 & 53.1 \\
\hline \multicolumn{5}{|l|}{ Farm occupations } \\
\hline Milking & 140 & 74.1 & 63 & 44.1 \\
\hline Cattle corralling & 111 & 58.7 & 64 & 44.8 \\
\hline Cattle bath & 97 & 51.3 & 35 & 24.5 \\
\hline Vaccination & 93 & 49.2 & 61 & 42.7 \\
\hline Fumigation & 61 & 32.3 & 41 & 28.7 \\
\hline Cattle slaughtering & 33 & 17.5 & 17 & 11.9 \\
\hline Farm barbed-wiring & 31 & 16.4 & 36 & 25.2 \\
\hline \multicolumn{5}{|l|}{ Animals in the residence place } \\
\hline Dog & 135 & 71.4 & 101 & 70.6 \\
\hline Cattle & 126 & 66.7 & 101 & 70.6 \\
\hline Horse & 79 & 41.8 & 84 & 58.7 \\
\hline Hen & 76 & 40.2 & 93 & 65.0 \\
\hline Cat & 73 & 38.6 & 93 & 65.0 \\
\hline Pig & 57 & 30.2 & 47 & 32.9 \\
\hline Sheep & 16 & 8.5 & 7 & 4.9 \\
\hline Goat & 9 & 4.8 & 3 & 2.1 \\
\hline
\end{tabular}

(continues) 
Table 1 (continued)

\begin{tabular}{lcccc}
\hline Variables & \multicolumn{2}{c}{ North } & \multicolumn{2}{c}{ Magdalena Medio } \\
& $\mathbf{n}$ & $\mathbf{\%}$ & $\mathbf{n}$ & $\mathbf{\%}$ \\
\hline Hygiene-sanitary characteristics & & & & \\
$\quad$ Hand washing before eating and cooking & 185 & 97.9 & 134 & 93.0 \\
$\quad$ Preparation of food derived from raw milk & 97 & 51.3 & 72 & 50.3 \\
$\quad$ Consumption of food derived from raw milk & 157 & 83.1 & 85 & 59.4 \\
$\quad$ Consumption of raw milk & 80 & 42.3 & 30 & 21.0 \\
Self-report of medical history * & & & & \\
Headache & 62 & 32.8 & 55 & 38.5 \\
Fever & 52 & 27.5 & 49 & 34.3 \\
Chills & 36 & 19.0 & 47 & 32.9 \\
Fatigue & 34 & 18.0 & 21 & 14.8 \\
Stomachache & 32 & 16.9 & 25 & 17.5 \\
Myalgia & 25 & 13.2 & 17 & 11.9 \\
$\quad$ Nausea & 24 & 12.7 & 21 & 14.7
\end{tabular}

IR: interquartile range.

* Corresponds to a self-report made by each participant of the study about the occupational history and after asking if he/she thinks that some of the mentioned signs and/or symptoms occur frequently.

\section{Description of some characteristics and history of clinical and veterinary management of cattle}

Three hundred and eighty-four bovines were evaluated in total. In the North subregion, the studied bovine population were 192 females, most of them born at the farm, with a median age of 60 months. Regarding the breeds tested in this region, $79.2 \%$ were Bos taurus and $20.8 \%$ were crossbreeds (Table 2). The proportions of male and female bovines studied in Magdalena Medio (192 cattle) were similar. The median age was 20 months. Studied breeds under mainly included Bos indicus animals (43.2\%), different crossbreeds (34.4\%), B. taurus (18.2\%) and Colombian creole breeds (4.2\%) (Table 2).

\section{Results of the serological screening in humans and cattle from both subregions}

Seropositivity was obtained for Anaplasma, Ehrlichia, Rickettsia, and Coxiella genera in individuals and cattle from the six municipalities analyzed. When analyzing the frequency of positive samples for both types of antibodies at the same time, 11.7\% (45/384) was found for Anaplasma, 46.4\% (178/384) for Ehrlichia, 41.1\% (158/384) for Rickettsia, and 27.1\% (104/384) for Coxiella; on the other hand, the human population showed a 29.2\% (97/332) frequency for Anaplasma; 59.9\% (199/332) for Ehrlichia, $52.1 \%$ (173/332) for Rickettsia, and 31.9\% (106/332) for Coxiella (Table 3).

The highest frequency of anti-Anaplasma spp. IgM antibodies in people was detected in San Pedro de los Milagros, where 84.1\% (53/63) of the samples were positive. Anti-Ehrlichia spp. IgM antibodies were mostly found in Entrerríos in 98.4\% (62/63), and anti-Rickettsia spp. IgM antibodies were found in equal proportions in Belmira and San Pedro de los Milagros with 100\% (63/63) positivity. For antiC. burnetii IgM antibodies, the highest frequency was found in Belmira, with 98.4\% (62/63). Regarding the detection of IgG-type antibodies in every studied bacterial genus, the highest frequency of anti-Anaplasma spp. IgG was found in the municipality of Belmira, with 60.3\% (38/63). Anti-Ehrlichia spp. IgG was equally frequent in Entrerríos and San Pedro de los Milagros (84.1\%, 53/63). Analyzed samples from San Pedro de los Milagros showed the highest seropositivity for anti-Rickettsia spp. and anti-C. burnetii IgG, with 81\% (51/63) and 60.3\% (38/63) frequencies, respectively.

In cattle, the highest frequency of anti-Anaplasma spp. IgM antibodies was found in Puerto Berrío, with 64.1\% (41/64), whereas detection percentages of anti-Ehrlichia spp. IgM were observed in three municipalities alike: Entrerríos, Belmira and Puerto Berrío, with 87.5\% (56/64). The highest frequency 
Table 2

Characterization of the studied cattle population.

\begin{tabular}{|c|c|c|c|c|}
\hline \multirow[t]{2}{*}{ Variables } & \multicolumn{2}{|c|}{ North } & \multicolumn{2}{|c|}{ Magdalena Medio } \\
\hline & Median & IR & Median & IR \\
\hline Age (months) & 60 & $42-81$ & 20 & $9-60$ \\
\hline \multirow[t]{2}{*}{ Time cattle has been in the farm (months) } & 60 & $41-72$ & 14 & $8-48$ \\
\hline & $\mathbf{n}$ & $\%$ & $\mathbf{n}$ & $\%$ \\
\hline \multicolumn{5}{|l|}{ Sex } \\
\hline Male & - & - & 96 & 50.0 \\
\hline Female & 192 & 100.0 & 96 & 50.0 \\
\hline \multicolumn{5}{|l|}{ Breed * } \\
\hline Bos taurus ** & 152 & 79.2 & 35 & 18.2 \\
\hline Bos indicus ** & - & - & 83 & 43.2 \\
\hline Different crossbreeds & 40 & 20.8 & 66 & 34.4 \\
\hline Colombian creole breeds ** & - & - & 8 & 4.2 \\
\hline \multicolumn{5}{|l|}{ Type of livestock production } \\
\hline Meat & - & - & 98 & 51.0 \\
\hline Milk & 192 & 100.0 & 59 & 30.7 \\
\hline Breeding & - & - & 23 & 12.0 \\
\hline Dual purpose & - & - & 12 & 6.3 \\
\hline \multicolumn{5}{|l|}{ Place of origin of the bovine } \\
\hline Born at the farm & 168 & 87.5 & 148 & 77.1 \\
\hline Born in another farm & 24 & 12.5 & 44 & 22.9 \\
\hline \multicolumn{5}{|l|}{ History of clinical and veterinary management } \\
\hline None/Non-diseased & 187 & 97.4 & 192 & 100.0 \\
\hline Low milk production & 2 & 1.0 & - & - \\
\hline Fever & 1 & 0.5 & - & - \\
\hline Weight loss & 1 & 0.5 & - & - \\
\hline Milk fever and hypocalcemia & 1 & 0.5 & - & - \\
\hline
\end{tabular}

IR: interquartile range.

* Breeds were categorized to better note the frequencies;

** Bos indicus: within the group of bovines of Indian origin also known as zebu cattle, breeds like Brahman, Zebu, Gyr, and Simbrah were included; Bos taurus: bovines of European origin, within this group breeds like Holstein, Jersey, Ayrshire, Simmental, Brown Swiss, Normande, Senepol, and Swedish Red were included; Colombian creoles: Bon and Romosinuano.

of anti-Rickettsia spp. IgM antibodies was detected at equal values in Belmira and San Pedro de los Milagros $(96.9 \%, 62 / 64)$. For anti-C. burnetii IgM, the highest frequency was found in Belmira, where $100 \%(64 / 64)$ of samples tested positive. Regarding the detection of IgG antibodies in cattle, the highest frequency of anti-Anaplasma spp. IgG was 45.3\% (29/64), and 82.8\% (53/64) for anti-Ehrlichia spp. IgG, both proportions were detected in Puerto Berrío. The highest frequencies of anti-Rickettsia spp. IgG antibodies were 54.7\% (35/64), equally detected in San Pedro de los Milagros and Puerto Berrío. For anti-C. burnetii $\operatorname{IgG}$, the highest frequency $(42.2 \%, 27 / 64)$ was found in Entrerríos.

\section{Exploratory analysis of variables related to serological evidence of exposure in the studied human and animal populations}

No IgM antibody associated factors were observed in the four microorganisms analyzed in both subregions after a multivariate adjustment. However, after analyzing data on the detection of IgG antibodies in individuals from the North subregion, a significant increase in exposure to Anaplasma spp. 
Table 3

Frequencies of IgM/lgG antibodies detected simultaneously for the genera Anaplasma, Ehrlichia, Rickettsia and Coxiella in people and cattle from the North and Magdalena Medio subregions of the department of Antioquia, Colombia.

\begin{tabular}{|c|c|c|c|c|c|c|c|c|c|}
\hline \multirow{2}{*}{$\begin{array}{l}\text { Subregion/ } \\
\text { Municipality }\end{array}$} & \multirow{2}{*}{$\begin{array}{l}\text { Analyzed } \\
\text { samples }\end{array}$} & \multicolumn{2}{|c|}{ Anaplasma } & \multicolumn{2}{|r|}{ Ehrlichia } & \multicolumn{2}{|r|}{ Rickettsia } & \multicolumn{2}{|r|}{ Coxiella } \\
\hline & & \# & $\%(95 \% \mathrm{Cl})$ & $\#$ & $\%(95 \% \mathrm{Cl})$ & \# & $\%(95 \% \mathrm{CI})$ & $\#$ & $\%(95 \% \mathrm{Cl})$ \\
\hline \multicolumn{10}{|l|}{ People } \\
\hline \multicolumn{10}{|l|}{ North } \\
\hline Entrerríos & 63 & 27 & $42.9(30.5-56.0)$ & 52 & 82.5 (70.9-91.0) & 47 & $74.6(62.1-84.7)$ & 27 & $42.9(30.5-56.0)$ \\
\hline Belmira & 63 & 28 & $44.4(31.9-57.5)$ & 47 & $74.6(62.1-84.7)$ & 36 & $57.1(44.1-69.5)$ & 30 & $47.6(34.9-60.6)$ \\
\hline San Pedro de los & 63 & 34 & $54.0(40.9-66.6)$ & 49 & 77.8 (65.5-87.9) & 51 & $81.0(69.1-89.8)$ & 32 & $50.8(37.9-63.6)$ \\
\hline \multicolumn{10}{|l|}{ Milagros } \\
\hline Total & 189 & 89 & $47.1(39.8-54.5)$ & 148 & $78.3(71.7-84.0)$ & 134 & 70.9 (63.9-77.3) & 89 & $47.1(39.8-54.5)$ \\
\hline \multicolumn{10}{|l|}{ Magdalena Medio } \\
\hline Puerto Berrío & 50 & 2 & $4.0(0.5-13.7)$ & 27 & $54.0(39.3-68.2)$ & 17 & $34.0(21.2-48.8)$ & 9 & $18.0(8.6-31.4)$ \\
\hline Puerto Triunfo & 37 & 6 & $16.2(6.2-32.0)$ & 21 & $56.8(39.5-72.9)$ & 13 & $35.1(20.2-52.5)$ & 6 & $16.2(6.2-32.0)$ \\
\hline Puerto Nare & 56 & $-*$ & $-*$ & 3 & $5.4(1.1-14.9)$ & 9 & $16.1(7.6-28.3)$ & 2 & $3.6(0.4-12.3)$ \\
\hline Total & 143 & 8 & $5.6(2.4-10.7)$ & 51 & $35.7(27.8-44.1)$ & 39 & $27.3(20.2-35.4)$ & 17 & $11.9(7.1-18.4)$ \\
\hline Total (people) & 332 & 97 & $29.2(24.4-34.4)$ & 199 & $59.9(54.5-65.3)$ & 173 & $52.1(46.6-57.6)$ & 106 & 31.9 (26.9-37.2) \\
\hline \multicolumn{10}{|l|}{ Cattle } \\
\hline \multicolumn{10}{|l|}{ North } \\
\hline Entrerríos & 64 & 4 & $6.3(1.7-15.2)$ & 29 & $45.3(32.8-58.3)$ & 26 & $40.6(28.5-53.6)$ & 23 & $35.9(24.3-48.9)$ \\
\hline Belmira & 64 & 2 & $3.1(0.4-10.8)$ & 33 & $51.6(38.7-64.3)$ & 33 & $51.6(38.7-64.3)$ & 24 & $37.5(25.7-50.5)$ \\
\hline San Pedro de los & 64 & 11 & $17.2(8.9-28.7)$ & 37 & $57.8(44.8-70.1)$ & 34 & $53.1(40.2-65.7)$ & 25 & $39.1(27.1-52.1)$ \\
\hline \multicolumn{10}{|l|}{ Milagros } \\
\hline Total & 192 & 17 & $8.9(5.24-13.8)$ & 99 & $51.6(44.3-58.8)$ & 93 & $48.4(41.2-55.7)$ & 72 & $37.5(30.6-44.8)$ \\
\hline \multicolumn{10}{|l|}{ Magdalena Medio } \\
\hline Puerto Berrío & 64 & 20 & $31.3(20.2-44.1)$ & 47 & $73.4(60.9-83.7)$ & 33 & $51.6(38.7-63.3)$ & 11 & $22.0(8.9-28.7)$ \\
\hline Puerto Triunfo & 64 & 7 & $10.9(4.5-21.3)$ & 25 & $39.1(27.1-52.1)$ & 22 & $34.4(23.0-47.3)$ & 14 & $21.9(12.5-34.0)$ \\
\hline Puerto Nare & 64 & 1 & $1.6(0.04-8.4)$ & 7 & $10.9(4.5-21.3)$ & 10 & $15.6(7.8-26.9)$ & 7 & $10.9(4.5-21.3)$ \\
\hline Total & 192 & 28 & $14.6(9.9-20.4)$ & 79 & $41.1(34.1-48.5)$ & 65 & $33.9(27.2-41.0)$ & 32 & $16.7(11.7-22.7)$ \\
\hline Total (cattle) & 384 & 45 & $11.7(8.7-15.4)$ & 178 & $46.4(41.3-51.5)$ & 158 & 41.1 (36.2-46.3) & 104 & $27.1(22.7-31.8)$ \\
\hline
\end{tabular}

\#: number of positive samples; $95 \% \mathrm{Cl}$ : $95 \%$ confidence interval.

* Without positive data for IgM/IgG antibodies detected at same time.

infection was observed, which is directly related to the length of time (in years) of work with cattle and to the direct contact with cattle in work activities performed in farms. However, in the Magdalena Medio subregion such relation involved the participation in livestock corralling. The exposure to Rickettsia spp. in the North subregion showed greater likelihood in individuals who performed milking and vaccination, as well as in participants who reported having dogs in their residence. In the Magdalena Medio subregion, no associated factors with Rickettsia spp. infection were observed. Regarding exposure to Ehrlichia spp., no associated factors in the North subregion were found; however, in Magdalena Medio, individuals who had direct occupational contact with cattle presented a higher probability of exposure to infection by this microorganism. Participants from the North subregion who reported tick bite history, participation in livestock slaughter and cohabitation with hens in their residence showed a higher probability of presenting serological evidence of exposure to $C$. burnetii. Data analysis from Magdalena Medio showed a greater probability of exposure to infection by this zoonotic agent in people consuming raw milk products.

In the Magdalena Medio subregion, it was observed that serological evidence (IgG antibodies) for exposure to Anaplasma spp. and anti-Rickettsia spp. in cattle significantly increased with age. Exposure 
to C. burnetii increased significantly and was related to the period cattle had been in the farms (regardless of their origin), thus resulting in the detection of $\operatorname{IgG}$ antibodies in bovines from the North subregion (Table 4).

\section{Table 4}

Exploratory analysis of variables related with seropositive (IgG antibodies) to Anaplasma, Ehrlichia, Rickettsia and Coxiella in the analyzed people and cattle from the North and Magdalena Medio subregions of the department of Antioquia, Colombia.

\begin{tabular}{|c|c|c|}
\hline Variable & OR * & $95 \% \mathrm{Cl}$ \\
\hline \multicolumn{3}{|l|}{ People } \\
\hline \multicolumn{3}{|l|}{ North subregion } \\
\hline \multicolumn{3}{|l|}{ Anaplasma spp. } \\
\hline Time working with cattle (in years) & 1.04 & $1.00-1.08 * *$ \\
\hline Direct occupational contact with cattle & 3.43 & $1.00-11.71$ ** \\
\hline \multicolumn{3}{|l|}{ Rickettsia spp. } \\
\hline Participation in milking & 2.64 & $1.08-6.43 * *$ \\
\hline Participation in vaccination & 4.07 & $1.53-10.84$ ** \\
\hline Having dogs in the place of residence & 6.14 & $2.26-16.66 * \star \star$ \\
\hline \multicolumn{3}{|l|}{ Coxiella burnetii } \\
\hline Participation in livestock slaughtering & 3.76 & $1.35-10.45$ ** \\
\hline History of tick bites & 6.18 & $1.12-34.07 * \star$ \\
\hline Having hens in the place of residence & 3.61 & $1.32-9.79 * \star$ \\
\hline \multicolumn{3}{|l|}{ Magdalena Medio subregion } \\
\hline \multicolumn{3}{|l|}{ Anaplasma spp. } \\
\hline Participation in livestock corralling & 3.43 & $1.22-9.63 * *$ \\
\hline Time working with cattle (in years) & 1.90 & $1.21-3.26 * *$ \\
\hline \multicolumn{3}{|l|}{ Ehrlichia spp. } \\
\hline Direct occupational contact with cattle & 2.59 & $1.02-6.57 * \star$ \\
\hline Participation in fumigation & 0.34 & $0.15-0.78 * \star$ \\
\hline \multicolumn{3}{|l|}{ Coxiella burnetii } \\
\hline Consuming foods derived from raw milk & 4.04 & $1.58-10.34 * \star$ \\
\hline Time working with cattle (in years) & 6.16 & $2.28-16.4 * \star \star *$ \\
\hline \multicolumn{3}{|l|}{ Cattle } \\
\hline \multicolumn{3}{|l|}{ North subregion } \\
\hline \multicolumn{3}{|l|}{ Coxiella burnetii } \\
\hline Time cattle has been in the farm & 2.45 & $1.02-6.08 * \star$ \\
\hline Ticks control method & 1.69 & $1.13-3.27 * \star \star$ \\
\hline \multicolumn{3}{|l|}{ Magdalena Medio subregion } \\
\hline \multicolumn{3}{|l|}{ Anaplasma spp. } \\
\hline Age & 1.79 & $1.12-3.63 * \star$ \\
\hline Ticks control method & 1.21 & $1.31-8.26 * *$ \\
\hline \multicolumn{3}{|l|}{ Rickettsia spp. } \\
\hline Age & 1.99 & $1.15-6.57 * \star$ \\
\hline Type of livestock production & 0.75 & $0.73-8.58 * \star$ \\
\hline
\end{tabular}

95\% Cl: 95\% confidence interval; OR: odds ratio.

Note: for Coxiella burnetii were considered seropositive results against both phase I and II IgG antibodies.

* Adjusted by logistic regression;

** $\mathrm{p}<0.05$;

$\star * \star p<0.01$. 


\section{Discussion}

In this study, serological signs of exposure to Anaplasma, Ehrlichia, Rickettsia and Coxiella genera were detected in bovines and in people working in cattle raising in the North and Magdalena Medio subregions. This finding denotes the circulation of these zoonotic agents in the livestock context in the studied subregions, suggesting that their role as potential etiological agents of associated infectious diseases must be considered to establish some type of differential diagnosis for both cattle and humans.

IFA is the most used technique for screening the studied type of infections; however, this test is hindered by the interference of cross-reactions between different microorganisms. For example, species from the genus Anaplasma exhibit seroreactivity between them, as well as with other Rickettsia and Ehrlichia, given the existing phylogenetical relation that was demonstrated through the analysis of the 16S rRNA gene 17. Likewise, there are reports of the occurrence of coinfections of C. burnetii and species from the Rickettsia genus 18 . Therefore, for cases that require more specific species differentiation, future studies should explore serological screening methods with molecular techniques like polymerase chain reactions and in vitro culture ${ }^{19}$. In addition, it is important to consider that the cut-off point used in this study was employed for screening and research in apparently healthy people working at farms; higher cut-off points values, measured in paired serum (seroconversion), should be employed in clinical diagnosis and treatment, according to the dynamics of antibodies production of each zoonosis 20 . Accordingly, if higher cut-off points were used, the frequencies reported in this study are expected to be lower since they would indicate active diseases, not exposure in the livestock context.

A. phagocytophilum is considered the etiologic agent of human granulocytic anaplasmosis. In Colombia, there are reports of cases in people working at livestock farms in the departments of Bolívar 15, Córdoba and Sucre, where exposure to this zoonotic agent has been suggested 21. Regarding cattle, reports claim the possibility of these animals being asymptomatically infected by Anaplasma spp. 22 , in some instances, this species has been considered the cause of conditions such as fever, anemia, and of decrease in milk production depending on the animal's age or immune status 23 . In species like Anaplasma marginale, a recognized etiological agent of bovine anaplasmosis, an extensive genetic strain diversity has been described 24, which may be related to various courses of clinical evolution in this type of infection. Considering IgG seropositivity associated factors for Anaplasma in bovines from the Magdalena Medio subregion, the findings of this study suggest that exposure increased significantly with age, similarly to Wesonga et al. 25 .

Anaplasma has been detected in Rhipicephalus microplus cattle ticks, in Dermacentor nitens collected from horses 13, and in R. microplus, Amblyomma cajennense and Amblyomma maculatum ticks collected in buffaloes 26 , demonstrating a wide circulation in diverse hosts and potential vector species. Clinical reports show that Anaplasma transmission does not occur exclusively by tick bites, documents in the literature link this microorganism to transmission through blood transfusions 27 , such transmission route for this microorganism is still poorly understood. Transplacental transmission has also been reported as the infection of calves has been observed since birth, thus becoming a potential infection source for other hosts 28 . In addition, mechanical transmission has been reported through fomites contaminated with infected blood 29 or through diptera of the Tabanus and Stomoxys genera ${ }^{30}$. Several animals, such as cattle, horses, goats, buffaloes, and canids are involved in the life cycle of Anaplasma. Infections have been reported in tropical countries like Colombia, Costa Rica and Brazil.

On the other hand, there is currently little evidence recording the circulation of the Ehrlichia species related to cattle or to the livestock context in Colombia, which contrasts with the exposure to Ehrlichia genus found in this study. However, literature reports exposure to Ehrlichia ruminantium in bovines from cattle systems in Tanzania 31 and molecular detection of this microbial agent in cattle systems in Turkey ${ }^{32}$. In Colombia, Ehrlichia species has been detected in hosts such as dogs, and Ehrlichia canis infection has been identified as the cause canine monocytic ehrlichiosis 33; also, its relation to infections in human cases has been suggested. In countries like Costa Rica, the circulation of this species has been detected in samples from blood donors ${ }^{34}$, while in Brazil, studies made in rural areas have shown exposure to E. canis in dogs and E. chaffensis in humans and horses 35 . Some studies have shown the circulation of Ehrlichia sp. in bovine ticks (R. microplus), and in dog ticks (Rhipicephalus san- 
guineus). E. canis, Anaplasma platys and A. phagocytophilum have been detected in dog ticks in tropical countries like Costa Rica 36, where cases in humans have also been diagnosed. This microorganism has a high diversity of host species. E. chaffeensis has been described as the species responsible for human monocytic ehrlichiosis; further, it has also been identified as an etiological agent of infections in dogs and cattle, among other animals. Susceptibility to this zoonotic agent has been experimentally tested in bovine cattle, causing fever, lethargy and in some severe cases, the death of the animal 37.

Regarding the results obtained in this study about the exposure of people and cattle from the studied regions to the Rickettsia genus, several research in Colombia have consistently suggested the circulation of spotted fever group rickettsiosis detected in equines (horses, mules and donkeys) and cattle 38 . $R$. rickettsii is considered the most virulent species in the group responsible for the Rocky Mountain spotted fever, whose vector-borne transmission can be transstadial and transovarial 6, with $10-60 \%$ of cases described as fatal if not treated rapidly. In countries like Costa Rica, the circulation of different Rickettsia species has been confirmed both in ticks associated to different hosts like horses, cattle, and dogs, and in humans 39. In Panamá, spotted fever group rickettsiosis have been isolated in ticks from domestic animals in areas near the Colombian border 40, suggesting their potential circulation in other tropical countries. In addition, the circulation of A. cajennense ticks extracted from skin and clothing of people has also been detected, suggesting the affinity of these arthropods for humans 12. IFA is the most used technique to diagnose rickettsial diseases; however, the presence of cross-reactions between the different species of Rickettsia and with other bacterial genera must be considered. Although in vitro culture screening is the reference test for Rickettsia, its application is not common given the need for a Biosafety Level 3 Laboratory. Therefore, in clinical instances with symptomatic patients, other aspects must be considered for the diagnosis, such as seroconversion and higher cut-off points for antibody titers $\geq 1: 64$ for $\operatorname{IgG}$ and $\geq 1: 32$ for IgM 41 .

Regarding the exploration of associated factors with the detection of anti-Rickettsia IgG antibodies, the results of this study suggest a higher probability of infection by this microorganism in people engaged with milking and vaccination activities in cattle farms, as well as in people who have dogs in their household. The presence of several animals at home, dogs and horses being the most frequent, was noted after the survey analysis. This information is important since these animals have been reported as hosts of several of the microorganisms tested in this study. This last observation coincides with a recent report performed in urban areas of Costa Rica, in which dogs were found to have a serological imprint of exposure to spotted fever group rickettsiosis, especially in places with known human infections. These findings hypothesize that dogs could be infection vectors in these scenarios 42 , which highlights the importance of the associated factors identified in this study as variables to be considered by the human and animal health sectors in subsequent studies seeking to identify the transmission dynamics of this type of zoonotic agent in the Colombian environment.

The exploration of the associated factors with seropositivity for C. burnetii found in people evaluated in this study proved that there is a greater probability of exposure to this microorganism in people who reported tick biting history and the consumption of food derived from raw milk. These factors are biologically plausible because vector-borne transmission of C. burnetii is considered secondary, and the main transmission mechanisms such as inhalation, contact with biological fluids from infected animals, and ingestion of contaminated products have been described. C. burnetii has been detected in different biological fluids like urine, feces, milk, and placenta of infected animals; tropism of this microbial agent by cells of the reproductive system has been evidenced, thus affecting consumers of unpasteurized milk 43 . Corroborating these results, C. burnetii has been previously detected in bovine milk from Colombia 44. In addition, serological evidence of exposure to this zoonotic agent in people engaged in livestock activities has also been reported in the departments of Córdoba and Sucre, in towns like La Ceja, Envigado and Caracoli, also being found in other Antioquia regions 45. In some cases, $C$. burnetii has been linked to chronic cardiac conditions, such as endocarditis 46 , in people with occupational exposure to livestock. IFA is the most used method to diagnose C. burnetii; cross-reactions have also been detected, in this case, with Bartonella species 47 . All these aspects must be considered for its diagnosis, in addition to the patient's clinical history and seroconversion during clinical evolution.

In Latin America, C. burnetii infection has been reported in people living in rural areas dedicated to livestock activities in Minas Gerais, Brazil 48. In Argentina, exposure to this zoonotic agent was 
reported in people living under poor sanitary conditions with domestic animals, such as cats and dogs 49 . In countries like Spain, exposure to this microorganism has been detected in dairy cattle 50 and in sheep. Regarding the detection of this agent in ticks, it has been described in the Amblyomma and Rhipicephalus genera of specimens collected in Brazil, Colombia, Kenya, and China 51. McDaniel et al. 52 suggests that coxiellosis, or Q fever, should be one of the highly suspected zoonotic diseases in people with occupational exposure to cattle, and that early diagnoses must be made to achieve successful treatments, given the serious medical conditions, like endocarditis, observed in 65\% of cases. Based on these data, we suggest that $C$. burnetii infections should also be considered in the Colombian environment for a differential and etiological diagnosis in people occupationally exposed to livestock, especially if they are used to consuming raw milk and raw milk-derived foods.

Anthropogenic activities related to the livestock production system are known to favor the contact with animals and hence, the development of zoonotic diseases. Although the North and Magdalena Medio subregions of Antioquia present contrasting ecological and productive conditions, the exposure of cattle and humans to the studied microorganisms was detected in both subregions. Milk production is considered the main economic and agricultural activity in Northern Antioquia, while breeding and dual-purpose activities are more frequent in livestock systems in the Magdalena Medio subregion 53 .

Climate change and global warming have been described as enhancers of the geographical expansion of vectors related to infectious diseases in the livestock context 54 , benefiting the development of diseases that affect both animals and humans. Moreover, ungulates have been cited as the main vertebrate hosts of zoonotic pathogens when compared to animals like rodents, primates, and bats 55 . The distribution of zoonotic agents related to cattle has also been claimed to be similar throughout the Americas, as well as in Oceania, Africa, Asia, and Europe 52. Although the results obtained in this study are relevant, some of them remain as research questions to be answered with greater certainty in future longitudinal studies. For example, it could be important to determine how different cattle breeds, dairy farming vs breeding and dual-purpose activities, cattle management characteristics, weather, and tick infestation rates could be influencing the exposure dynamics to these zoonotic agents in the studied regions.

According to this study, time of work and direct contact with cattle (milking, vaccination, livestock slaughtering and corralling) were associated with the exposure to the studied zoonotic agents. Therefore, occupational health measures must be addressed in the livestock cattle context, taking biosecurity actions in the work field, such as the proper use of face masks, gloves, boots, preventive actions against tick bites, among others. Consumption of raw milk and foods derived from it must be considered when studying the transmission of this kind of zoonotic agents (as it has been demonstrated for C. burnetii) so control procedures are adequately followed. In addition, considering that people working in livestock activities in Colombia are exposed to the studied infections, the infectious agents involved should be included in differential and etiological diagnoses for clinical cases of acute febrile syndrome in people with this type of occupation. In general, the findings from this study indicate the exposure to these microorganisms in the livestock context. Consequently, promotion and prevention programs specifically aimed at this type of occupational exposure are required, thus addressing this problem in a comprehensive, cooperative and articulated manner in public and animal health sectors. 


\section{Contributors}

M. P. Eraso-Cadena performed research, analyzed data and wrote the paper. L. P. Molina-Guzmán designed research, performed research and analyzed data. X. Cardona designed research and performed research. J. A. Cardona-Arias and L. A. RíosOsorio designed research and analyzed data. L. A. Gutierrez-Builes designed research, analyzed data and wrote the paper.

\section{Acknowledgments}

We thank UMATAs (Unidades Municipales de Asistencia Técnica Agropecuaria) and the livestock associations COREGAN (Comité Regional de Ganaderos de Puerto Berrío), COOLETRIUNFO (Cooperativa Multiactiva Lechera de Puerto Triunfo), and APAGRONAR (Asociación de Productores Agropecuarios de Puerto Nare) for the logistic support provided at sampling in the North and Magdalena Medio subregions. To COLCIENCIAS (grant number 121056934576-Contract 653-2013, CIDI UPB 211B-02/14-65) for the financial support.

\section{References}

1. Centers for Disease Control and Prevention. Emerging tickborne diseases 2017. https:// www.cdc.gov/cdcgrandrounds/archives/ 2017/March2017.htm (accessed on 03/May/ 2017).

2. Organización Mundial de la Salud. Informe de un comité de expertos de la salud (OMS), con participación de la FAO. Geneva: Organización Mundial de la Salud; 1982. (Reporte, 682).

3. Instituto Colombiano Agropecuario. Censo Pecuario Nacional, 2016. https://www.ica.gov. co/getdoc/8232c0e5-be97-42bd-b07b-9cd bfb07fcac/Censos-2012.aspx (accessed on 15/ Jun/2016).

4. Manzano R, Díaz V, Perez R. Garrapatas: características anatómicas, epidemiológicas y ciclo vital. Detalles de la influencia de las garrapatas sobre la producción y sanidad animal. Revista Argentina de Producción Animal 2012; 8:1-8.

5. Organización Mundial de Sanidad Animal. Enfermedades, infecciones e infestaciones de la lista de la OIE en vigor en 2017. http:// www.oie.int/es/sanidad-animal-en-el-mun do/oie-listed-diseases-2017/ (accessed on 20/ Nov/2017).

6. Bauerfeind R, von Graevenitz A, Kimmig P, Schiefer HG, Schwarz T, Slenczka W, et al. Zoonoses: infectious diseases transmissible between animals and humans. 4th Ed. Washington DC: ASM Press; 2016.

7. Cortés JA, Romero LF, Aguirre CA, Pinzón L, Cuervo SI. Enfoque clínico del síndrome febril agudo en Colombia. Infectio 2017; 21:39-50.

8. Dantas F, Chomel BB, Otranto D. Ticks and tick-borne diseases: a one health perspective. Trends Parasitol 2012; 28:437-46.

9. Cortés JA, Betancourt JA, Argüelles J, Pulido LA. Distribución de garrapatas Rhipicephalus (Boophilus) microplus en bovinos y fincas del Altiplano cundiboyacense (Colombia). Corpoica Ciencia y Tecnología Agropecuaria 2010; 11:73-84.

10. Estrada A. Ticks as vectors: taxonomy, biology and ecology. Rev Sci Tech 2015; 34:53-65.

11. Ríos S, Gutiérrez L, Ríos L. Assessing bovine babesiosis in Rhipicephalus (Boophilus) microplus ticks and 3 to 9-month-old cattle in the middle Magdalena region, Colombia. Pesqui Vet Bras 2014; 34:313-9.

12. Faccini AA, Ramírez A, Forero E, Cortés JA, Escandón P, Rodas JD, et al. Molecular evidence of different Rickettsia species in Villeta, Colombia. Vector Borne Zoonotic Dis (Larchmont, NY) 2016; 16:85-7.

13. Miranda J, Mattar S. Molecular detection of Anaplasma sp. and Ehrlichia sp. in ticks collected in domestical animals, Colombia. Trop Biomed 2015; 32:726-35.

14. Montes J, De La Vega F, Bello A, Fortich AS. Coinfección de babesiosis y ehrlichiosis: un caso en Cartagena de Indias, Colombia. Revista Ciencias Biomédicas 2012; 3:339-45. 
15. Gómez V, Arroyo BJ, Bello AA, Rodríguez Z, Polo ER. Diagnóstico microbiológico compatible con Anaplasma sp. en un paciente con síndrome febril. Rev Argent Microbiol 2015; 47:78-9.

16. Máttar S, Contreras V, Gonzáles M, Camargo F, Álvarez J, Oteo JA. Infection by Coxiella burnetii in a patient from a rural area of Monteria, Colombia. Rev Salud Pública 2014; 16:958-61.

17. Battilani M, De Arcangeli S, Balboni A, Dondi F. Genetic diversity and molecular epidemiology of Anaplasma. Infect Genet Evol 2017; 49:195-211.

18. Santos A, de Sousa R, Alves F, Proença P, Núncio M, Dumler J, et al. Isolation of Coxiella burnetii from the blood of a patient with positive Anaplasma phagocytophilum serological results. Clin Microbiol Infect 2009; 15 Suppl 2:192-3.

19. Máttar S. Utilidad de la biología molecular en el estudio de las zoonosis. MVZ Córdoba 2000; 5:46-50.

20. Ismail N, McBride JW. Tick-borne emerging infections erhlichosis and anaplasmosis. Clin Lab Med 2017; 37:1-24.

21. Máttar S, Parra M. Detection of antibodies to Anaplasma, Bartonella and Coxiella in rural inhabitans of the Caribbean area of Colombia. MVZ Córdoba 2006; 11:781-9.

22. Woldehiwet Z. The natural history of Anaplasma phagocytophilum. Vet Parasitol 2010; 167:108-22.

23. Organización Mundial de Sanidad Animal. Manual terrestre de la OIE - anaplasmosis bovina. http://www.oie.int/fileadmin/Home/ esp/Health_standards/tahm/2.04.01_Anaplas mosis_bovina.pdf (accessed on 17/Jun/2017).

24. Mtshali M, De La Fuente J, Ruybal P, Kocan K, Vicente J, Mbati PA, et al. Prevalence and genetic diversity of Anaplasma marginale strains in cattle in South Africa. Zoonoses Public Health 2007; 54:23-30.

25. Wesonga FD, Gachohi JM, Kitala PM, Gathuma JM, Njenga MJ. Seroprevalence of Anaplasma marginale and Babesia bigemina infections and associated risk factors in Machakos County, Kenya. Trop Anim Health Prod 2017; 49:265-72.

26. Barbosa J, da Fonseca AH, Barbosa JD. Molecular characterization of Anaplasma marginale in ticks naturally feeding on buffaloes. Infect Genet Evol 2015; 35:38-41.

27. Fine AB, Sweeney JD, Nixon CP, Knoll BM. Transfusion-transmitted anaplasmosis from a leukoreduced platelet pool. Transfusion 2016; 56:699-704.

28. Aubry P, Geale D. A review of bovine anaplasmosis. Transbound Emerg Dis 2011; 58:1-30.

29. Kocan KM, de la Fuente J, Blouin EF, Coetzee JF, Ewing SA. The natural history of Anaplasma marginale. Vet Parasitol 2010; 167:95-107.
30. Scoles GA, Broce AB, Lysyk TJ, Palmer GH. Relative efficiency of biological transmission of Anaplasma marginale (Rickettsiales: Anaplasmataceae) by Dermacentor andersoni (Acari: Ixodidae) compared with mechanical transmission by Stomoxys calcitrans (Diptera: Muscidae). J Med Entomol 2005; 42:668-75.

31. Swai ES, Mtui PF, Changa AK, Machange GE. The prevalence of serum antibodies to Ehrlichia ruminantium infection in ranch cattle in Tanzania: a cross-sectional study. J S Afr Vet Assoc 2008; 79:71-5.

32. Aktas M, Altay K, Dumanli N. Molecular detection and identification of Anaplasma and Ehrlichia species in cattle from Turkey. Ticks Tick Borne Dis 2011; 2:62-5.

33. Cartagena LM, Ríos LA, Cardona JA. Seroprevalencia de Ehrlichia canis en perros con sospecha de infección por patógenos transmitidos por garrapatas en Medellín, 2012-2014. Rev Med Vet (Bogota) 2015; 29:51-62.

34. Bouza L, Dolz G, Solórzano A, Romero JJ, Salazar L, Labruna MB, et al. Novel genotype of Ehrlichia canis detected in samples of human blood bank donors in Costa Rica. Ticks Tick Borne Dis 2017; 8:36-40.

35. da Costa RF, Wischra ST, Gomes D, Martins TF, Krawczak FS, Labruna MB, et al. Serological survey of Ehrlichia species in dogs, horses an humans: zoonotic scenery in a rural settlement from southern brazil. Rev Inst Med Trop São Paulo 2013; 55:335-40.

36. Campos L, Äbregon L, Solórzano A, Alberti A, Tore G, Zobba R, et al. Molecular detection and identification of Rickettsiales pathogens in dog ticks from Costa Rica. Ticks Tick Borne Dis 2016; 7:1198-202.

37. de los Santos JR, Boughan K, Bremer WG, Rizzo B, Schaefer JJ, Rikihisa Y, et al. Experimental infection of dairy calves with Ehrlichia chaffeensis. J Med Microbiol 2007; 56:1660-8.

38. Barreto C, Faccini A, Forero E, Ramirez A, Cortés J, Polo L, et al. Evidencia serológica de exposición a rickettsias del grupo de las fiebres manchadas en bovinos del municipio de Villeta, Cundinamarca. Acta Méd Costarric 2013; 55 Suppl 1:77-8.

39. Hun L. Rickettsiosis en Costa Rica. Acta Med Costarric 2013; 55 Suppl 1:25-8.

40. Bermúdez SE, Eremeeva ME, Karpathy SE Samudio F, Zambrano ML, Zaldivar Y, et al. Detection and identification of rickettsial agents in ticks from domestic mammals in Eastern Panama. J Med Entomol 2009; 46:856-61.

41. Oteo JA, Nava S, Sousa R, Mattar S, Venzal JM, Abarca K, et al. Guías latinoamericanas de la RIICER para el diagnóstico de las rickettsiosis transmitidas por garrapatas. Rev Chil Infectol 2014; 31:54-65. 
42. Moreira A, Carranza MV, Taylor L, Calderón O, Hun L, Troyo A. Exposure of dogs to spotted fever group rickettsiae in urban sites associated with human rickettsioses in Costa Rica. Ticks Tick Borne Dis 2016; 7:748-53.

43. Sins KA, Stobierski MG, Gandh TN. Q fever cluster among raw milk drinkers, Michigan, 2011. Clin Infect Dis 2012; 55:1387-9.

44. Contreras V, Máttar S, González M, Álvarez J, Oteo J. Coxiella burnetii in bulk tank milk and antibodies in farm workers at Montería, Colombia. Rev Colomb Cienc Pecu 2015; 28:1817.

45. Betancur CA, Rubio M, Barrera J, Bedoya JC. Seroprevalence of Coxiella burnetii in cattle farm workers in the department of Antioquia. Acta Med Colomb 2015; 40:20-3.

46. Betancur CA, Munera AG. Endocarditis por Coxiella burnetii: fiebre Q. Acta Med Colomb 2012; 37:31-3.

47. Martín L, Vidal L, Campins A, Salvá F, Riera M, Carrillo A, et al. Bartonella as a cause of blood culture-negative endocarditis. Description of five cases. Rev Esp Cardiol 2009; 62:694-7.

48. Costa PSG, Brigatte ME, Greco DB. Antibodies to Rickettsia rickettsii, Rickettsia typhi, Coxiella burnetii, Bartonella henselae, Bartonella quintana and Ehrlichia chaffeensis among healthy population in Minas Gerais, Brazil. Mem Inst Oswaldo Cruz 2005; 100:853-9.

49. Cicuttin GL, Degiuseppe JI, Mamianetti A, Corin MV, Linares MC, De Salvo MN, et al. Serological evidence of Rickettsia and Coxiella burnetii in humans of Buenos Aires, Argentina. Comp Immunol Microbiol Infect Dis 2015; 43:57-60.
50. Alvarez J, Perez A, Mardones FO, Pérez M, García T, Pagés E, et al. Epidemiological factors associated with the exposure of cattle to Coxiella burnetii in the Madrid region of Spain. Vet J 2012; 194:102-7.

51. Machado E, Vizzoni VF, Balsemao E, Moerbeck L, Gazeta GS, Piesman J, et al. Coxiella symbionts are widespread into hard ticks. Parasitol Res 2016; 115:4691-9.

52. McDaniel CJ, Cardwell DM, Moeller RB, Gray GC. Humans and cattle: a review of bovine zoonoses. Vector Borne Zoonotic Dis (Larchmont, NY) 2014; 14:1-19.

53. Gobernación de Antioquia. Plan de desarrollo "Antioquia piensa en grande" 2016-2019. http://www.antioquia.gov.co/images/pdf/ ORDENANZA PLAN DE DESARROLLO DE ANTIOQUIA 2016-2019_FirmaEscaneada. pdf (accessed on 15/Apr/2018).

54. Wu X, Lu Y, Zhou S, Chen L, Xu B. Impact of climate change on human infectious diseases: empirical evidence and human adaptation. Environ Int 2016; 86:14-23.

55. Woolhouse MEJ, Gowtage S. Host range and emerging and reemerging pathogens. Emerg Infect Dis 2005; 11:1842-7. 


\section{Resumen}

Las bacterias pertenecientes a los géneros Anaplasma, Ehrlichia, Rickettsia y Coxiella son consideradas patógenos emergentes y la ganadería es uno de los contextos donde se puede producir la transmisión de este tipo de microorganismos. El objetivo de este estudio fue determinar la evidencia serológica, debida a la exposición a estas bacterias en bovinos y humanos con exposición ocupacional a ganadería en las subregiones Norte y Magdalena Medio, Antioquia, Colombia, además de estudiar los factores relacionados. Se realizó un estudio transversal en 48 fincas ganaderas, distribuidas en seis municipios de ambas subregiones: Belmira, Entrerríos y San Pedro de los Milagros (Norte), y Puerto Berrío, Puerto Nare y Puerto Triunfo (Magdalena Medio). Las muestras de sangre de 332 personas y 384 bovinos fueron evaluadas mediante tamización serológica (IgM e $\operatorname{Ig} G$ ) para la detección de bacterias de los géneros Anaplasma, Ehrlichia, Rickettsia, y Coxiella. La seropositividad en humanos de ambas regiones fue 42,4\% (IC95\%: 31,2-55,1) en el caso de Anaplasma, un 74,2\% (IC95\%: 66,0-84,4) en Ehrlichia, un 72,5\% (IC95\%: 62,1-82,0) en Rickettsia, y un 60,7\% (IC95\%: 59,7-69,1) en Coxiella burnetii. En los bovinos, la seropositividad fue 31,6\% (IC95\%: 19,9-44,2), 66,8\% (IC95\%: 55,2-78,1), 64,6\% (IC95\%: 53, 8- 74,5), y 61,6\% (IC95\%: 51,9$69,2)$, respectivamente. El antecedente de haber sido mordido por garrapatas, ordeñar, vacunación, tener perros y gallinas en la residencia, así como el consumo de derivados de leche cruda fueron algunos de los factores asociados con la infección por las bacterias estudiadas. Los resultados sugieren la exposición previa y reciente a estas bacterias en personas con una exposición ocupacional a la ganadería, así como a los bovinos en las dos subregiones estudiadas.

Zoonosis; Serología; Bovinos; Salud Laboral

\section{Resumo}

As bactérias dos gêneros Anaplasma, Ehrlichia, Rickettsia $e$ Coxiella são considerados patógenos emergentes, e a transmissão desses microrganismos pode ocorrer no contexto da pecuária. O estudo teve como objetivos determinar as evidências sorológicas de exposição a essas bactérias em bovinos e em humanos com exposição ocupacional ao gado nas sub-regiões Norte e Magdalena Médio, Antióquia, Colômbia, e explorar fatores associados. Foi realizado um estudo transversal em 48 fazendas de gado bovino distribuídas em seis municípios nas duas sub-regiões: Belmira, Entrerrios e San Pedro de los Milagros (Norte) e Puerto Berrío, Puerto Nare e Puerto Triunfo (Magdalena Médio). Amostras de sangue de 332 humanos e 384 bovinos foram analisadas com sorologia (IgM e IgG) para bactérias dos gêneros Anaplasma, Ehrlichia, Rickettsia e Coxiella. Os niveis de sorologia positiva em humanos das duas regiões foram de 42,4\% (IC95\%: 31,2-55,1) para Anaplasma, 74,2\% (IC95\%: 66,0-84,4) para Ehrlichia, 72,5\% (IC95\%: 62,1-82,0) para Rickettsia e 60,7\% (IC95\%: 59,7-69,1) para Coxiella burnetii. Nos bovinos, os niveis foram 31,6\% (IC95\%: 19,944,2), 66, 8\% (IC95\%: 55, 2-78, 1), 64,6\% (IC95\%: 53, 8-74,5) e 61,6\% (IC95\%: 51,9-69,2), respectivamente. Os fatores associados às bactérias estudadas foram: história de picada de carrapato, ordenha, vacinação, presença de cães e galinhas no domicílio e consumo de laticínios feitos com leite cru, entre outros. Os resultados sugerem exposição prévia e recente a esses gêneros bacterianos zoonóticos em pessoas com contato ocupacional com gado, assim como nos próprios animais, nas duas sub-regiões estudadas.

Zoonoses; Sorologia; Bovinos; Saúde do Trabalhador
Submitted on 09/Nov/2017

Final version resubmitted on 04/May/2018

Approved on 08/Jun/2018 